\section{COVID 19: Knowledge, opinions and prevention among the populace}

Modupeoluwa Omotunde SOROYE, Babatope Bamidele OSAGBEMIRO

[Department of Preventive Dentistry, Faculty of Dentistry, University of Port Harcourt, Port Harcourt Rivers State]

\section{Correspondence}

Dr. Modupeoluwa O. Soroye

Department of Preventive Dentistry, Faculty of Dentistry, University of Port Harcourt, Port Harcourt Rivers State

Email: docdupe@yahoo.com

Modupeoluwa O. Soroye

https://orcid.org/ 0000-0001-9909-0381

Babatope B. Osagbemiro

https://orcid.org/ 0000-0003-4085-545

\section{ABSTRACT}

Objective: There was a lot of panic when the COVID-19 pandemic started because a lot was not known about it. However, as the disease unfolded, proven scientific universal precautions are recommended to curb its spread.

Methods: This was a cross-sectional online survey of people living in Nigeria. Questionnaires were distributed to consenting participants using the SurveyMonkey and data was collected on sociodemographic knowledge of the aetiology and prevention of COVID-19. Analysis was done with the SPSS version 25 .

Results: Eighty-five participants with age ranging from 18 to 60 years took part in the study. The mean age was $37.35 \pm$ $11.7 y e a r s . ~ F o r t y-s e v e n ~(47 \%)$ had knowledge that COVID-19 infection is from a virus. $29.4 \%$ thought it is caused by biological weapons, $1.2 \%$ from $5 \mathrm{G}$ internet, $7.1 \%$ as government's ploy to embezzle money and $9.4 \%$ conspiracy theory from the world leaders to reduce world's population. All participants knew that hand washing is a preventive measure against the spread of COVID-19 and majority agreed to the use of sanitizers, social distancing and disinfection of surfaces. Only $30.6 \%$ agreed that wearing of facemasks will serve as a preventive measure. Over $90 \%$ of the participants agreed that dissemination of appropriate information, use of universal precautions, isolation and intensive treatment of those infected can help prevent the spread of COVID-19. $11.8 \%$ of participants knew that additional precautions are needed for aerosol generating procedures.

Conclusion: The knowledge of COVID-19 aetiology is poor among the populace and the need to wear face masks as a preventive measure in curtailing the spread of COVID-19 needs to be emphasized.

Keywords: Aetiology, Covid 19, Knowledge, Prevention

Received: 4 Oct, 2021

Revision: 3 Nov, 2021

Accepted: 4 Nov, 2021

Citation: Soroye MO, Osagbemiro BB. COVID 19: Knowledge, opinions and prevention among the populace. Nig J Dent Res 2022; 7(1):35-44 


\section{Introduction}

The devastating effect of the Covid-19 pandemic demands that public health measures be emphasized in order to mitigate it. Coronavirus disease (COVID19 ) is caused by the novel coronavirus called Severe Acute Respiratory Syndrome Coronavirus 2 (SARSCoV-2) which emerged in late 2019 and has caused a global public health threat that resulted in a pandemic in many countries and territories. 1,2

Although projections that Africa will be the next epicenter of the COVID-19 pandemic because of inadequacy of medical personnel and facilities have overtime been proved wrong; it is still of importance to ensure preventive public health measures despite the fact that the mortality rate is less when compared with the developed countries.3/4 The World Health Organization (WHO) approved the practice of preventive measures for the maintenance of the health of the public. These measures include the use of face masks, using soap and running water or sanitizer to clean the hands and a practice of maintaining two meters of physical distance. Others are to cover the mouth and nose when coughing such as coughing into the elbow, and to avoid touching the face. ${ }^{5}$

Nigeria's first case of COVID-19 was imported by an Italian citizen on the February 27, 2020 and the first fatality occurred on the $23^{\text {rd }}$ of March, 2020. ${ }^{6,7}$ By August 17, 2021, there were 183,444 confirmed cases and 2229 deaths in Nigeria, ${ }^{10} 735.862$ confirmed cases and 185,706 deaths in Africa ${ }^{9}$ and 208,470,375 confirmed cases and 4, 377,979 deaths reported worldwide. ${ }^{8}$ These figures continue to increase as mass screening and testing are done.

Consumption of infected animals such as (bats and pangolins) by humans have been named as a source of infection for SARS-CoV-2.$^{11}$ It has been reported that both symptomatic and asymptomatic patients are contagious but it is not yet clear how long the virus shedding is prolonged or how its transmissibility is altered during the natural history of the disease. ${ }^{9}$

The believed predominant routes of transmission are through respiratory droplets which is similar to the mode of transmission of other observed respiratory viral infections. ${ }^{12}$ Thus, person-to-person transmission of SARS-CoV-2 are through droplets and contact with infected persons. Other unconfirmed routes which are considered potential ones are aerosol and faeco-oral transmissions. ${ }^{13}$
Aerosols are droplets that contain pathogens such as viruses or bacteria that are suspended in the air for a period of time. They can be transferred over some distance along air currents and can serve as potential long-distance transmission of diseases. ${ }^{14,15}$

The general population is susceptible to COVID-19 infection with no preference for gender sex or age. Reports showed that older people (over 50 years old) and children (<10 years old) accounted for $53.6 \%$ and $0.9 \%$ of cases respectively. ${ }^{16,17}$ Individuals who have other underlying co-morbidities such as pre-existing respiratory infection, cancer, hypertension, cardiovascular disease and diabetes mellitus are more likely to succumb to the disease, develop severe forms of COVID-19 and have serious complications. ${ }^{13,18,19}$

It has been said that knowledge influences attitudes, and practices are an important aspect of disease prevention in the face of health emergencies and outbreaks. Health education and promotion which are used to communicate and engage the public are very important in order to prevent the quick spread of infections. ${ }^{20}$ However despite all this information, many Nigerians are of the opinions that there are other reasons responsible for the cause of the COVID-19 pandemic.

This study assessed the knowledge of aetiology and preventive measures of CoVID-19 infection among the Nigeria population.

\section{Materials and Methods}

This cross-sectional online survey was done in March 2020 on people living in Nigeria. Questionnaires were distributed to consenting participants using SurveyMonkey which is a cloud-based survey tool that can be used to create, send and analyse surveys. It was created in 1999. The participants gave implied consent by clicking on the 'next' button in answering the questionnaire, and clicking on the 'submit' button was taken as submission. Confidentiality was maintained by giving only the principal investigator the access to the data and the personal details of responders (name, phone numbers and e-mail addresses) were not requested.

The sampling methods used were convenience (researchers themselves contacted people through WhatsApp and phone calls) and snowball (people were asked to forward the questionnaire to their friends) because the study was done during the lockdown in the early phase of the COVID-19 
pandemic. Participants were from all facets of life. They understand English language, could use the internet, they are from all parts of Nigeria and are above 18 years of age.

Data was collected on knowledge of COVID-19 aetiology and prevention. Analysis was carried out with Statistical Package for Social Science (SPSS) version 25 (IBM Corp., Armonk, USA) after extraction from the SurveyMonkey. Descriptive statistics was reported as means and frequencies.

\section{Results}

Table 1 shows the participants' demographics. Eighty-five [85(100\%)] participants comprising of 43 male and 42 females took part in the study. Majority of the participants were in the third and fifth decades of life. The age ranged between 18 and 60 years of age with mean age of $37.4 \pm 11.7$ years.

About half [40(47.0\%)] of the participants knew that the causative agent of COVID-19 is a virus. More than a quarter [25(29.4\%)] thought it is used as biological weapons, $[1(1.2 \%)] 5 \mathrm{G}$ internet, $6(7.1 \%)$ thought it is the government's ploy to embezzle the country's money and [8(9.4\%)] thought it is a conspiracy theory from the world leaders to reduce the world's population. (Table 2)

All participants [85(100\%)] knew that hand washing serves as a preventive measure for the spread of Table 1. Participants' demographics

\begin{tabular}{lll} 
Variables & Frequency & Percentage \\
Sex & & \\
Female & 43 & 50.6 \\
Age group & 42 & 49.4 \\
$10-20$ & 6 & 7.1 \\
$21-30$ & 24 & 28.2 \\
$31-40$ & 19 & 22.4 \\
$41-50$ & 26 & 30.5 \\
$51-60$ & 10 & 11.8 \\
Education & & \\
Primary education & 4 & 5.7 \\
Secondary education & 11 & 12.9 \\
Post -secondary education & 18 & 21.2 \\
Tertiary education & 52 & 61.2 \\
Occupation & & \\
Civil servants & 18 & 21.2 \\
Health personnel & 27 & 31.7 \\
Retired & 6 & 7.1 \\
Self-employed. & 15 & 17.6 \\
Students & 19 & 22.4 \\
Total & 85 & 100.0 \\
\hline Mean age & &
\end{tabular}

Mean age $=37.35 \pm 11.7 y e a r s$
COVID-19 infection and 83(97.6\%) agreed to the use of sanitizers and social distancing. While $75(88.2 \%)$ agreed on disinfection of surfaces, one third of the participants [26(30.6\%)] agreed that wearing of facemasks will serve as a preventive measure. (Table 3)

Eighty-two (96.5\%) of the participants agreed that dissemination of appropriate information to the populace, use of universal precautions, informing health care workers when one is infected and isolation and intensive treatment of those infected can help reduce the spread of infection. Only half [48(56.5\%)] of them believed that wearing face masks while handling infected persons can prevent infection. Very few $10(11.8 \%)$ of the participants knew that additional precautions are needed for aerosol producing procedures. (Table 4)

Although, $81(95.3 \%)$ of the participants claimed that being infected with COVID-19 infection is not an automatic death sentence, $80(94.1)$ said it should be treated in the hospitals and not at home. (Table 4) Sixty-eight $(80 \%)$ of the participants believed that closure of the country's borders will reduce spread of infection. 30(35.3\%) believed that handling of pets (Table 4) like cats and dogs can spread COVID-19 infection. 
Table 2 Participant's knowledge of the aetiology of COVID-19

\begin{tabular}{lll}
\hline Variables & Frequency & Percentage \\
\hline Virus from animals & & \\
Yes & 40 & 47.0 \\
No & 14 & 16.5 \\
Don't Know & 31 & 36.5 \\
Internet 5G & 1 & \\
Yes & 65 & 1.2 \\
No & 19 & 76.4 \\
Don't know & & 22.4 \\
Biological weapon & 25 & \\
Yes & 28 & 29.4 \\
No & 32 & 32.9 \\
Don't know & 6 & 37.7 \\
Government ploy to embezzle money & \\
Yes & 52 & 7.1 \\
No & 27 & 61.2 \\
Don't know & 8 & 31.7 \\
New world order to reduce the world population (conspiracy theory) & \\
Yes & 42 & 9.4 \\
No & 35 & 49.4 \\
Don't know & 85 & 41.2 \\
Total & & 100.0 \\
\hline
\end{tabular}

Table 3. Participant's knowledge of what COVID-19 preventive measures are

\begin{tabular}{lll}
\hline Variables & Frequency & Percentage \\
\hline $\begin{array}{l}\text { Hand washing } \\
\text { Yes }\end{array}$ & 85 & 100.0 \\
Prayers & & \\
Yes & 55 & 64.7 \\
No & 30 & 35.3 \\
Sanitizers & & \\
Yes & 83 & 97.6 \\
No & 2 & 2.4 \\
Facemasks & & \\
Yes & 26 & 30.6 \\
No & 59 & 69.4 \\
Social distancing & & \\
Yes & 83 & 97.6 \\
No & 2 & 2.4 \\
Disinfect surfaces & & \\
Yes & 75 & 88.2 \\
No & 10 & 11.8 \\
Total & 85 & 100.0 \\
\hline
\end{tabular}


Table 4. Participants' general knowledge about COVID-19 pandemic

\begin{tabular}{|c|c|c|}
\hline Variables & Frequency & Percentage \\
\hline \multicolumn{3}{|c|}{ Transmission can be prevented using universal precautions } \\
\hline Yes & 82 & 96.5 \\
\hline No & 3 & 3.5 \\
\hline \multicolumn{3}{|c|}{ Any COVID-19 information should be disseminated among peers } \\
\hline Yes & 82 & 96.5 \\
\hline No & 3 & 3.5 \\
\hline \multicolumn{3}{|c|}{ People diagnosed with COVID-19 should be in isolation } \\
\hline Yes & 83 & 97.6 \\
\hline No & 2 & 2.4 \\
\hline \multicolumn{3}{|c|}{ Intensive treatment should be given to patients diagnosed with COVID-19 } \\
\hline Yes & 82 & 96.5 \\
\hline No & 3 & 3.5 \\
\hline \multicolumn{3}{|c|}{ Information about COVID-19 should be given to all the populace } \\
\hline Yes & 84 & 9 \\
\hline No & 1 & 1.2 \\
\hline \multicolumn{3}{|c|}{ Additional precautions should be taken for aerosols generating procedure } \\
\hline Yes & 10 & 11.8 \\
\hline No & 75 & 88.2 \\
\hline \multicolumn{3}{|c|}{ Health workers should be informed when one has symptoms } \\
\hline Yes & 84 & 98.8 \\
\hline No & 1 & 1.2 \\
\hline \multicolumn{3}{|c|}{ Gowns and eye goggles are a must when handling COVID-19 patients } \\
\hline Yes & 77 & 90.6 \\
\hline No & 8 & 9.4 \\
\hline \multicolumn{3}{|c|}{ COVID-19 patients should be managed in the house } \\
\hline Yes & 5 & 5.9 \\
\hline No & 80 & 94.1 \\
\hline \multicolumn{3}{|c|}{ Wearing facemask will protect from COVID-19 } \\
\hline Yes & 48 & 56.5 \\
\hline No & 27 & 31.8 \\
\hline Don't know & 10 & 11.7 \\
\hline \multicolumn{3}{|c|}{ Getting COVID-19 is an automatic death sentence } \\
\hline Yes & 1 & 1.2 \\
\hline No & 81 & $95 \cdot 3$ \\
\hline Don't know & 3 & 3.5 \\
\hline \multicolumn{3}{|c|}{ Border Closing will stop the spread of COVID-19 } \\
\hline Yes & 68 & 80.0 \\
\hline No & 12 & 14.1 \\
\hline Don't Know & 5 & 5.9 \\
\hline \multicolumn{3}{|c|}{ Pets can spread COVID -19 infection } \\
\hline Yes & 30 & $35 \cdot 3$ \\
\hline No & 24 & 28.2 \\
\hline Don't know & 31 & 36.5 \\
\hline Total & 85 & 100.0 \\
\hline
\end{tabular}




\section{Discussion}

There are misconceptions among Nigerians as regards the aetiology and preventive measures that can be used to reduce the spread of COVID-19 despite the information being given by $\mathrm{WHO}$ and the Nigeria Center for Disease Control (NCDC). This study examined the knowledge of the aetiology and preventive measures against COVID-19 infection and eighty-five subjects participated in this study; $61.2 \%$ of them had tertiary education.

The causative agent of COVID-19 infection is a coronavirus which belongs to the Coronaviridae family that cause respiratory infection in mammals (bats, camels and masked palm civets) and avian species. ${ }^{13,21}$ The symptoms of coronavirus infection have been reported to vary across different hosts. ${ }^{22}$ It may be asymptomatic in humans or manifest as fever, cough, shortness of breath and gastrointestinal irritation. ${ }^{11,}{ }^{23}$ In the elderly and immunocompromised, the infections may lead to severe pneumonia and eventually, the death of the patient. ${ }^{24}$

In this study, $47.0 \%$ of participants knew that the cause of COVID-19 infection is a virus. This is lower when compared to a study done in North-Central Nigeria that reported 91.7\%. ${ }^{25}$ However, it compares favourably with the study done in Iran which reported that $56.5 \%$ of their participants knew that the virus is the organism responsible for COVID-19..$^{26}$ This is because though many Nigerians have heard of COVID-19 as reported by the Nigerian study, not many knew about the causative agent. ${ }^{25}$ The study assessed COVID-19 awareness rather than its aetiological agent. ${ }^{25}$

Furthermore, in this study, more than a quarter (29.4\%) of the participants was of the opinion that the aetiology is biological weapons designed by the Chinese Government. Another study done in Nigeria reported that $46.9 \%$ of their participants also believed this. ${ }^{27} \quad$ Furthermore, $1.2 \%$ of the participants mentioned $5 \mathrm{G}$ internet. $7.1 \%$ thought COVID-19 is a scam and the government's ploy to embezzle the country's money while $9.4 \%$ thought it is a conspiracy theory from the world leaders to reduce the world's population. $35.3 \%$ are of the opinion that handling of pets like cats and dogs can spread COVID-19 infection. These suggested aetiologies are prosperous and outrageous especially while considering the fact that almost two-third of the participants have tertiary education and should be able to access the correct information and help disseminate them among the populace.

Recommendations have been made on how to stay safe by using simple non-pharmaceutical measures like washing the hands with water and soap or using sanitizers, maintaining at least a distance of 2 meters away from another person (physical-distancing), wearing of face masks. ${ }^{28,29}$ Others are to keep rooms well ventilated, avoid crowds, and cough into a bent elbow or tissue. ${ }^{28,29}$ Surprisingly, all participants knew that hand washing is preventive for the spread of COVID-19 infection and this compares to another study that reported that $94.3 \%$ of their participants had same knowledge. ${ }^{27}$ In this study, $97.6 \%$ agreed to the use of sanitizers and physical distancing. However, less than one-third (30.6\%) of the participants agreed that wearing of facemasks will serve as a preventive measure. This contrasts with the studies done in Jordan and Saudi Arabia which reported that $68.4 \%$ and $87.2 \%$ of their participants respectively knew that wearing of facemask can prevent infection. ${ }^{30,31}$ Studies reported that many Nigerians believe that COVID-19 is unreal since the fatality rate is low in the country and they do not see the need to use face masks. ${ }^{30-32}$ Furthermore, many feel that wearing facemasks for a long time is uncomfortable. ${ }^{32}$

Two-thirds (66.7\%) of participants in our study are of the opinion that praying is effectual in preventing COVID-19. Another study done in North-Central Nigeria reported that $45.3 \%$ of their respondents' believed this also. ${ }^{25}$ This is not surprising as it has been reported that there is strict adherence to religious beliefs among Nigerians and this has resulted in increased carefree and lackadaisical attitudes that make them rely on only prayers and religious rituals during disease outbreaks bypassing necessary precautionary measures. ${ }^{33}$ It has been advised that religious leaders and clerics should be directly involved by the Nigerian Government in the fight against COVID-19 so they can help disseminate factual and scientific based information about it among their followers. ${ }^{33}$ Furthermore, another study done in Nigeria showed that many Nigerians because of their superstitious beliefs and poor knowledge of the scientific facts regarding COVID-19 prefer only to pray, use herbs like garlic and ginger, anointing oils and talisman, do steam inhalation or even perform 
religious rituals. ${ }^{33}$ Thus, they violate the preventive measures such as not maintaining physical distance and not using face masks in churches and mosques. ${ }^{33}$ Studies have reported that performing aerosol generating procedures like tracheal intubation, dental procedures and extubation, administering treatments that generate aerosols such as bilevel positive airway pressure ventilation and high-flow nasal cannulas, and handling infected persons can transmit the COVID-19 virus. ${ }^{34-40}$ It has been reported that COVID-19 infected persons can transmit infection through direct contact or indirectly through contaminated surfaces or objects and daily disinfection of their living environment, (high touch surfaces, bathtubs and toilet bowls) is essential. ${ }^{41,42}$ Dental procedures also have high-risk transmission route due to handling of sharp instruments and tools as well as possible contamination with saliva and blood during treatment. 43

In view of the above, recommendations were made to disinfect surrounding surfaces and use additional personal protective equipment (PPE) such as airpurifying respirator, a gown, gloves and $\mathrm{N}_{95}$ mask with a face shield despite the fact that they can result in the need to increase rate of breathing, reduce field of vision, tactile sensation, and heat stress 39,40 Majority (90.6\% ) of the participants knew that surgical gowns and eye goggles should be used while handling infected persons but half $(56.5 \%)$ ] of them did not believe that wearing face masks while handling infected persons could protect the care givers. Only $11.8 \%$ of the participants knew that additional precautions are needed for aerosol producing procedures, though $88.2 \%$ of participants agreed that surfaces at home and at work should be disinfected to reduce spread of infection. This reflects a better knowledge in this area compared to the study that reported that only half (48.9\%) of their participants were of the opinion that surfaces should be disinfected. ${ }^{27}$

At the beginning of the COVID-19 pandemic, nonpharmaceutical interventions (NPIs) were used to prevent the spread of infection through governmental (curfews, travel and social gathering bans, lockdowns and self-initiated measures (increased personal hygiene, physical distancing, use of face masks) to alter individuals' behaviours. ${ }^{44}$ Eighty percent of the participants agreed that closure of the country's borders will reduce spread of infection.

Never before in human history has it been possible to communicate so quickly during a pandemic and social media platforms have been key for the dissemination of information (new, relevant, scientific, diagnosis, treatment and follow-up protocols) despite the associated multiple advantages and disadvantages. ${ }^{45}$ However, one has to follow basic guidelines in doing so, especially during the pandemic. ${ }^{45,46}$ Over $90 \%$ of the participants agreed that dissemination of appropriate information to the populace, use of universal precautions, informing health care workers when one is infected and isolation and intensive treatment of infected people can help reduce the spread of COVID-19 infection. It is very important to disseminate correct information as studies have reported that people's level of knowledge about infectious diseases usually modifies their behaviour to prevention. 47,48

Being infected with COVID-19 is not an automatic death sentence because the mortality rate is low and not all who are infected die from it.49-54 However, it was estimated that 1 in every 20 persons infected will require intensive care treatment (sedation and ventilator). ${ }^{55}$ Though $95.3 \%$ of the participants in this study agreed that being infected with COVID-19 infection is not an automatic death sentence, 5.9\% said that those infected should be treated at home using herbs and prayers rather than in the isolation centers. This is not surprising because the populace had various care preferences for the disease. ${ }^{33}$

In conclusion, it is important to disseminate information to correct the wrong opinions held by the populace and to lay emphasis on the need to use all public health preventive measures if the spread of COVID-19 infection is to be curtailed among the populace. This is in spite of inappropriate beliefs and the low mortality rate.

\section{Limitation}

This study was constrained by the low number of respondents captured as data could only be collected online because of the lockdown in Nigeria at the time of the study. The use of non-probability sampling techniques also limited inferences and conclusions that could be ascribed to the study. (Convenience and snowballing). 


\section{Acknowledgement}

We acknowledge all who volunteered to fill the questionnaire for this study

\section{Source of Support: Nil}

Conflict of interest: None Declared

\section{References}

1. Rodriguez-Morales AJ, Bonilla-Aldana DK, Balbin-Ramon GJ et al. History is repeating itself: probable zoonotic spillover as the cause of the 2019 novel coronavirus epidemic. Infez Med 28:3-5.

2. Dhama $\mathrm{K}, \mathrm{Khan} \mathrm{S}$, Tiwari $\mathrm{R}$ et al. Coronavirus Disease 2019-COVID-19. Clin Microbiol Rev. 2020; 33: e00028-20.

3. Massinga-Loembé M, Tshangela A, Salyer SJ et al. COVID-19 in Africa: the spread and response. Nat Med 2020; 26: 999-1003.

4. World Health Organization, 2020. Coronavirus. Geneva Switzerland: WHO [homepage on the internet], Port Harcourt. [updated 2021 September 30; cited 2021 October 1]. Available from: https://www.who.int/health-topics/ coronavirus $\#$ tab=tab2.

5. Apanga PA, Lettor IBK, Akunvane R. Practice of COVID-19 Preventive Measures and Its Associated Factors among Students in Ghana. The American Journal of Tropical Medicine and Hygiene 2020; 104:526-531.

6. Ahmad AS, Aminu S, Usman AA, Suleiman AS. Estimation of the case fatality rate of COVID-19 epidemiological data in Nigeria using statistical regression analysis,

Biosafety and Health 2021; 3: 4-7.

7. Salako O, Okunade $K$, Habeebu $M$ et al. Upheaval in cancer care during the COVID-19 outbreak. E-cancer medical science, 14 (2020), Article ed97.

8. Covid-19 update. [homepage on the internet] [updated 2021 September 30; cited 2021 October 4]. Available from: htpps/ncdc.gov.ng.

9. Covid 19 in Africa. [homepage on the internet] [updated 2021 September 30; cited 2021 October 4]. Available from: https://africacdc.org/covid-19.
10. Covid-19 information. [homepage on the internet] [updated 2021 September 28; cited 2021 October 1]. Available from: https://www.who.int/covid-19/information.

11. Chen NS, Zhou M, Dong X et al. Epidemiological and clinical characteristics of 99 cases of 2019 novel coronavirus pneumonia in Wuhan, China: a descriptive study. Lancet. 2020; 395:507-513.

12. Mallah SI, Ghorab OK, Al-Salmi S et al. COVID19: breaking down a global health crisis. Ann Clin Microbiol Antimicrob. 2021; 20:35.

13. De Wit $E$, van Doremalen $N$, Falzarano $D$, Munster VJ. SARS and MERS: recent insights into emerging coronaviruses. Nat Rev Microbiol. 2016; 14:523-534.

14. Ruan ZL, Huang M, Liang L et al. SARS-CoV-2 Viral Load in Upper Respiratory Specimens of Infected Patients. N Engl J Med. 2020; 382:11771179.

15. Guan WJ, Ni ZY, Hu Y et al. Clinical characteristics of coronavirus disease 2019 in China. N Engl J Med. 2020 Apr 30; 382(18):17081720.

16. Wax RS, Christian MD. Practical recommendations for critical care and anaesthesiology teams caring for novel coronavirus (2019-nCoV) patients. Can J Anaesth. 2020; 67:568-576.

17. Huang $C L$, Wang $Y M, L i ~ X W$ et al. Clinical features of patients infected with 2019 novel coronavirus in Wuhan, China. Lancet. 2020; 395:497-506.

18. Shi $Y$, Wang $G$, Cai XP et al. An overview of COVID-19. J Zhejiang Univ Sci B. 2020; 21:343360.

19. Ohia C, Bakarey AD, Ahmad T. COVID-19 and Nigeria: putting the realities in context. Int. J. Infect. Dis 2020; 95: 279-281.

20. El-Masry, Mohamed RA, Ali Rl, Al Mulhim MF, Taha AE. Novel coronavirus-disease-related knowledge, attitudes and practice among the residents of Al-Jouf region in Saudi Arabia. J Infect Dev Ctries 2021; 15:32-39.

21. Gong SR, Bao LL. The battle against SARS and MERS coronaviruses: Reservoirs and Animal Models. Anim. Model. Exp. Med. 2018; 1:125133 . 
22. Fehr AR, Perlman S. Coronaviruses: An overview of their replication and pathogenesis. Methods Mol. Biol. 2015; 1282:1-23.

23. Wilder-Smith A, Teleman MD, Heng $B H$ et al. Asymptomatic SARS coronavirus infection among healthcare workers, Singapore. Emerg. Infect. Dis. 2005; 11:1142-1145.

24. Jartti $L$, Langen $H$, Söderlund-Venermo $M$ et al. New respiratory viruses and the elderly. Open Respir. Med. J. 2011; 5:61-69.

25. Reuben RC, Danladi MM, Saleh DA, Ejembi PE. Knowledge, attitudes and practices towards COVID-19: an epidemiological survey in NorthCentral Nigeria. J Community Health. 2020:114.

26. Nemati M, Ebrahimi B, Nemati F. Assessment of Iranian nurses' knowledge and anxiety toward COVID-19 during the current outbreak in Iran. Archives of Clinical and Infectious Diseases Arch Clin Infect Dis. In Press: 2020: e102848.

27. Olapegba PO, Ayandele O, Kolawole SO et al. A preliminary assessment of novel coronavirus (COVID-19) knowledge and perceptions in Nigeria. http://dx.doi.org /10.2139 /ssrn .3584408 .

28. Ehsanifar M. Airborne aerosols particles and COVID-19 transition. Environmental Research 2021; 200:111752.

29. World Health Organization, [homepage on the internet] [updated 2021 October 2; cited 2021 October 4]. Available from: https://www.who.int/emergencies/diseases/ novel-coronavirus-2019/advice-for-public.

30. Chu DK, Akl EA, Duda $S$ et al. Physical distancing, face masks, and eye protection to prevent person-to-person transmission of SARSCoV-2 and COVID-19: a systematic review and meta-analysis. The Lancet. 2020; 395:19731987.

31. Alzoubi $\mathrm{H}$, Alnawaiseh $\mathrm{N}, \mathrm{Al}-$ Mnayyis $\mathrm{A}$ et al. COVID-19 - Knowledge, Attitude and Practice among Medical and Non-Medical University Students in Jordan. J. Pure Appl. Microbiol. 2020; 14: 17-24.

32. Al Naam YA, Elsafi SH, Alkharraz ZS, et al. Community practice of using face masks for the prevention of COVID-19 in Saudi Arabia. PLoS ONE 2021; 16: e0247313.

33. Ogoina D. COVID-19: The Need for Rational Use of Face Masks in Nigeria. Am J Trop Med Hyg. 2020; 103:33-34.

34. Musa S, Aifuwa HO. Coronavirus pandemic in Nigeria: How can small and medium enterprises (SME) cope and flatten the curve? European Journal of Accounting, Finance and Investment 2020; 6: 55-61.

35. Chen PZ, Bobrovitz N, Premji Z et al. Heterogeneity in transmissibility and shedding SARS-CoV-2 via droplets and aerosols. Elife. 2021; 10: e65774.

36. Asadi S, Wexler AS, Cappa CD et al. Effect of voicing and articulation manner on aerosol particle emission during human speech. PLOS ONE. 2020;15: e0227699

37. Bi $\mathrm{Q}, \mathrm{Wu} Y$, Mei $S$ et al. Epidemiology and transmission of COVID-19 in 391 cases and 1286 of their close contacts in Shenzhen, China: a retrospective cohort study. The Lancet Infectious Diseases. 2020; 20:911-919.

38. Chu CM, Cheng VC, Hung IF et al. Viral load distribution in SARS outbreak. Emerging Infectious Diseases. 2005; 11:1882-1886

39. Jayaweera $M$, Perera $H$, Gunawardana $B$, Manatunge J. Transmission of COVID-19 virus by droplets and aerosols: A critical review on the unresolved dichotomy, Environmental Research 2020; 188:109819.

40. Ruskin KJ, Ruskin AC, Musselman BT et al. COVID-19, Personal Protective Equipment, and Human Performance. Anesthesiology 2021; 134:518-525.

41. Visentin LM, Bondy SJ, Schwartz B, Morrison $L J$ : Use of personal protective equipment during infectious disease outbreak and non-outbreak conditions: A survey of emergency medical technicians. CJEM. 2015; 11:44-56.

42. Esakandari $H$, Nabi-Afjadi $M$, Fakkari-Afjadi J et al. A comprehensive review of COVID-19 characteristics. Biol Proced Online. 2020; 22:19.

43. Baghizadeh FM. What dentists need to know about COVID-19. Oral Oncol. 2020; 105:104741.

44. Lotfi M, Hamblin MR, Rezaei N. COVID-19: Transmission, prevention, and potential 
therapeutic opportunities. Clin Chim Acta. 2020; 508:254-266.

45. Perra N. Non-pharmaceutical interventions during the COVID-19 pandemic: A review. Phys Rep. 2021; 913:1-52.

46. Li HO, Bailey A, Huynh D, Chan J. YouTube as a source of information on COVID-19: a pandemic of misinformation? BMJ Glob Health. 2020; 5: e002604.

47. González-Padilla DA, Tortolero-Blanco L. Social media influence in the COVID-19 Pandemic. Int Braz J Urol. 2020; 46:120-124.

48. Choi JS, Yang NY. Perceived knowledge, attitude, and compliance with preventive behavior on influenza $A\left(\mathrm{H}_{1} \mathrm{~N}_{1}\right)$ by university students. J. Korean Acad. Adult Nurs. 2010; 22:250-259.

49. Hussain ZA, Hussain SA, Hussain FA. Medical students' knowledge, perceptions, and behavioral intentions towards the $\mathrm{H}_{1} \mathrm{~N}_{1}$ influenza, swine flu, in Pakistan: a brief report. Am. J. Infect. Control 2012; 40: e11-e13.

50. Matta S, Chopra KK, Arora VK. Morbidity and mortality trends of Covid 19 in top 10 countries. Indian J Tuberc. 2020; 67: S167-S172.
51. Paules $\mathrm{Cl}$, Marston HD, Fauci AS. Coronavirus infections-more than just the common cold. JAMA. 10.1001/jama.2020.0757.

52. Yang J, Zheng $Y$, Gou $X$. Prevalence of comorbidities in the novel Wuhan coronavirus (COVID-19) infection: a systematic review and meta-analysis. Int J Infect Dis. 2020; 94:91-95.

53. Tian $W$, Jiang $W$, Yao J, et al. Predictors of mortality in hospitalized COVID-19 patients: A systematic review and meta-analysis. J Med Virol. 2020; 92:1875-1883.

54. Jin JM, Bai P, He W, et al. Gender Differences in Patients With COVID-19: Focus on Severity and Mortality. Front Public Health. 2020; 8:152.

55. Matta S, Chopra KK, Arora VK. Morbidity and mortality trends of Covid 19 in top 10 countries. Indian J Tuberc. 2020; 67: S167-S172.

56. Supady A, Curtis JR, Abrams D, et al. Allocating scarce intensive care resources during the COVID-19 pandemic: practical challenges to theoretical frameworks. The Lancet Respiratory Medicine 2021; 9: 430-434. 